\title{
Dinamika Pemilihan Gubernur Jawa Timur
}

\author{
R. Nazriyah \\ Alumni Fakultas Hukum Universitas Islam Indonesia Yogyakarta \\ Jl. Tamansiswa No. 158 Yogyakarta \\ ririesnaya@yahoo.com
}

\begin{abstract}
This research is aimed at finding the reasons of the Board of Trustees of the General Election Committee (DKPP) in granting the charge of Khofifah Indar Parawansa and the reasons of the Constitutional Court in rejecting the charge related with the Regional Head Election of East Java in 2013. This research is a normative research with the approaches used consisting of Acts and Case studies. The data used are secondary data involving primary legal material, secondary legal material, and tertiary legal material. The data collected were then analyzed qualitatively. The result of the research concludes that according to the Costitutional Court, the Jalan Lain Menuju Kesejahteraan Rakyat (Jalin Kesra) program conducted by Soekarwo is not a fatal mistake in the Regional Head Election. According to the Constitutional Court, the program is a sustainable program initiated and conducted since 2010. Meanwhile, the consideration of DKPP to grant the charge of Khofifah-Herman is because the General Election Committee was proven of diminishing the party constitutional right to suggest a candidate in the Regional Head Election of East Java including Khofifah-Herman for the candidate for governor and deputy governor. The grant and social assisstance (bansos) program must be conducted in the first three years of the regional head governance so that there will not be an allegation of the grant and social assistance manipulation for campaign activities if the incumbent plans to be reelected.
\end{abstract}

Key words : Regional Head General Election, Board of Trustees of the General Election Committee, Constitutional Court

\begin{abstract}
Abstrak
Penelitian ini bertujuan untuk mengetahui alasan Dewan Kehormatan Penyelenggara Pemilihan Umum (DKPP) mengabulkan gugatan Khofifah Indar Parawansa dan alasan Mahkamah Konstitusi menolak gugatan Khofifah Indar Parawansa dalam Pemilukada Jawa Timur pada 2013. Penelitian ini merupakan penelitian yang bersifat normatif. Pendekatan penelitian yang digunakan meliputi pendekatan undang-undang dan pendekatan kasus. Jenis data yang digunakan adalah data sekunder. Sumber data sekunder yang digunakan mencakup bahan hukum primer, bahan hukum sekunder dan bahan hukum tersier. Data yang terkumpul kemudian dianalisis melalui analisa kualitatif. Hasil penelitian menyimpulkan, program Jalan Lain Menuju Kesejahteraan Rakyat (Jalin Kesra) yang dilakukan Soekarwo bukanlah kesalahan fatal dalam proses Pilkada. Menurut MK, program tersebut merupakan program berkelanjutan yang dimulai dan dilaksanakan sejak 2010. Sedangkan pertimbangan DKPP mengabulkan gugatan Khofifah-Herman karena KPU terbukti menghilangkan hak konstitusional partai untuk mengusulkan calon dalam Pemilukada Jatim termasuk kepada pasangan Khofifah-Herman sebagai cagub dan cawagub. Seharusnya program hibah dan bantuan sosial (bansos) dilaksanakan pada tiga tahun pertama pemerintahan kepala daerah, sehingga tidak ada dugaan manipulasi dana hibah dan bansos untuk kegiatan kampanye jika incumbent ingin mencalonkan kembali.
\end{abstract}

Kata kunci : Pemilukada, Gubernur, Dewan Kehormatan Penyelenggara Pemilihan Umum, Mahkamah Konstitusi 


\section{Pendahuluan}

Perkembangan berdemokrasi di daerah tumbuh luar biasa sejak lahirnya politik otonomi daerah yang bergulir begitu cepat. Seluruh kepala daerah dipilih secara langsung oleh rakyat sesuai dengan amanat undang-undang yang lahir di era reformasi - kecuali jabatan Gubernur Daerah Istimewa Yogyakarta (DIY). Di beberapa daerah pelaksanaan Pemilihan Kepala Daerah (Pilkada) melahirkan ketidakpuasan yang berujung pada pengajuan keberatan atas hasil Pilkada tersebut ke pengadilan dengan alasan yang beragam.

Di Jawa Timur misalnya, sudah dua kali periode (periode 2008-2013 dan periode 2013-2018) pelaksanaan Pemilukada menimbulkan sengketa. Sengketa Pemilukada di Jawa Timur tergolong unik, karena dua kali berturut-turut sengketa terjadi antara dua kandidat yang sama yaitu pasangan Soekarwo-Syaifullah Yusuf dengan Khofifah Indar Parawansa (pasangan Khofifah Indar Parawansa pada 2008 yaitu Mudjiono sedangkan pada 2013 berpasangan dengan Herman Suryadi Sumawiredja).

Jika sengketa Pemilukada pada 2008 terjadi hanya karena adanya keberatan terhadap rekapitulasi hasil penghitungan suara Pemilukada Jawa Timur, pada 2013 ini sengketa terjadi baik pada tahapan verifikasi pendaftaran calon Gubernur dan wakil Gubernur Jawa Timur maupun terhadap hasil penghitungan suara.

Pada tahapan verifikasi bakal calon Gubernur/Wakil Gubernur Jawa Timur terdapat dukungan ganda yang diberikan terhadap pasangan Khofiffah-Herman dan Soekarwo-Syaifullah Yusuf, yaitu dari Partai Kedaulatan dan Partai Persatuan Nahdlatul Ummah Indonesia (PPNUI). Terhadap dukungan ganda tersebut melahirkan pendapat berbeda dari komisioner KPU Provinsi Jawa Timur. Ketua KPU Andry Dewanto Ahmad dan anggota KPU Sayekti Suindyah menilai dukungan dari PK dan PPNUI kepada Khofiffah sah, karena ditandatangani oleh pengurus partai terbaru. Sementara dukungan terhadap pasangan Karsa ditandatangani oleh pengurus partai lama dan ada indikasi pemalsuan dokumen. Namun, tiga komisioner KPU lainnya menganggap dukungan tersebut tidak sah. ${ }^{1}$

Pasangan Khofifah-Herman digugurkan oleh KPU Jatim melalui Penetapan Nomor 18/Kpts/KPU.JTM-014/2013 tanggal 14 Juli 2013 sebagai calon gubernur dan wakil gubernur karena persentase dukungan dari partai politik kurang dari 15

${ }^{1}$ http:/ / www.republika.co.id.berita nasional jawa timur.soal khofifah dkpp kritik kpu jatim. Diakses tanggal 2 September 2013. 
persen. Akhirnya, pasangan Khofifah- Herman mengajukan gugatan kepada Dewan Kehormatan Penyelenggara Pemilu (DKPP). Khofifah-Herman menduga pencoretan dirinya sebagai calon Gubernur/Wakil Gubernur disebabkan adanya pemalsuan dukungan PPNUI dan Partai Kedaulatan (PK) ke pasangan lain. ${ }^{2}$

Sidang DKPP yang dipimpin oleh Jimly Asshiddiqie mengabulkan sebagian gugatan Khofifah - Herman dan memulihkan hak konstitusional atau memasukkan nama Khofifah-Herman sebagai calon gubernur/wakil gubernur. DKPP juga memerintahkan kepada Komisi Pemihan Umum (Pusat) untuk mengambil alih tanggung jawab KPU Provinsi Jawa Timur untuk sementara, dan melaksanakan putusan ini sebagaimana mestinya, serta kepada Badan Pengawas Pemilihan Umum Republik Indonesia untuk mengawasi pelaksanaan putusan ini. ${ }^{3}$

Khofifah-Herman akhirnya dapat mengikuti pertarungan dalam Pemilihan Umum Kepala Daerah Jawa Timur 2013. Dengan demikian, Pilkada Jatim diikuti oleh empat pasangan, yakni pasangan Bambang Dwi Hartono-Said Abdullah (Jempol), Khofifah Indar Parawansa-Herman S. Sumawiredja (Berkah), Eggi SudjanaMuhammad Sihat (Beres) dan pasangan Soekarwo-Saifullah Yusuf (Karsa).

Dalam pertarungan tersebut pasangan incumbent Soekarwo-Saifullah Yusuf diputus KPU Jatim memenangi Pilgub Jatim dengan memperoleh suara 8.195.816 suara atau 47,25 persen. Pasangan Khofifah-Herman (Berkah) menempati urutan kedua dengan memperoleh 6.525.015 suara atau 37,62 persen. Pasangan Bambang DH-Said Abdullah (Jempol) menempati urutan ketiga meraih 2.200.069 suara atau 12,69 persen. Dan pasangan perseorangan Eggi Sudjana-M Sihat (Beres) memperoleh 422.932 suara atau 2,44 persen. ${ }^{4}$

KPU Jawa Timur menetapkan Pasangan Soekarwo-Saifullah Yusuf sebagai Gubernur dan Wakil Gubernur Jawa Timur Periode 2013 - 2018. Tetapi, pasangan Khofifah-Herman (Berkah) tidak menerima keputusan KPU Jawa Timur tersebut dan mengajukan keberatan ke Mahkamah Konstitusi (MK). MK menolak gugatan sengketa pilkada gubernur Jawa Timur yang diajukan Khofifah Indar Parawansa. Atas hal ini maka Soekarwo-Saifullah Yusuf kembali menjadi gubernur untuk periode kedua kalinya.

\footnotetext{
${ }^{2}$ http://news.liputan6.com, Khofifah menang. Diakses tanggal 2 September 2013.

${ }^{3}$ http://news.detik.com.anggota kpu jatim sudah menduga khofifah menang di dkpp. Diakses tanggal 4 September 2013.

${ }^{4}$ http://news.detik.com.gugatan khofifah ditolak mk kukuhkan soekarwo jadi gubernur jatim. Diakses tanggal 10 Oktober 2013.
} 


\section{Rumusan Masalah}

Permasalahan yang akan diteliti adalah: pertama, mengapa Dewan Kehormatan Penyelenggara Pemilu mengabulkan gugatan pasangan KhofifahHerman (Berkah) dalam Pemilukada Jawa Timur pada 2013. Kedua, mengapa Mahkamah Konstitusi menolak gugatan pasangan Khofifah-Herman (Berkah) dalam Pemilukada Jawa Timur pada 2013.

\section{Tujuan Penelitian}

Tujuan penelitian ini adalah untuk mengetahui: pertama, alasan Dewan Kehormatan Penyelenggara Pemilu mengabulkan gugatan pasangan KhofifahHerman (Berkah) dalam Pemilukada Jawa Timur pada 2013. Kedua, alasan Mahkamah Konstitusi menolak gugatan pasangan Khofifah-Herman (Berkah) dalam Pemilukada Jawa Timur Pada 2013.

\section{Metode Penelitian}

Penelitian ini merupakan penelitian yang bersifat normatif. Pendekatan penelitian yang digunakan meliputi pendekatan perundang-undangan dan pendekatan kasus. Jenis data yang digunakan adalah data sekunder. Sumber data sekunder yang digunakan mencakup bahan hukum primer, bahan hukum sekunder, dan bahan hukum tersier. Bahan-bahan hukum primer terdiri dari perundangundangan, risalah dalam pembuatan perundang-undangan dan putusan-putusan hakim. ${ }^{5}$ Putusan Mahkamah Konstitusi (MK) yang diteliti adalah Putusan MK Nomor 117/PHPU.D-XI/2013 tentang Sengketa Pemilukada Jawa Timur. Teknik pengumpulan data yang digunakan berupa bahan pustaka melalui buku-buku literatur, peraturan perundang-undangan, serta pengumpulan data, melalui media elektronik yang berhubungan dengan masalah yang diteliti. Data yang terkumpul kemudian dianalisa melalui analisa kualitatif.

${ }^{5}$ Peter Mahmud Marzuki, Penelitian Hukum, Edisi Pertama,Cetakan Ke-4, Predana Media Group, Jakarta, 2008, hlm. 141. 


\section{Kontroversi Pemilihan Kepala Daerah Langsung}

Sejalan dengan sistem demokrasi perwakilan, maka secara kelembagaan perlu ada badan perwakilan rakyat daerah yang dibentuk secara demokratik. Demikian pula penyelenggaraan pemerintahannya harus dijalankan secara demokratik yang meliputi tata cara penunjukan pejabat, penentuan kebijakan, pertanggungjawaban, pengawasan, dan lain-lain. Mekanisme pemerintahan harus dilakukan dengan tata cara yang demokratik pula. ${ }^{6}$

Adanya organ politik dalam pelaksanaan otonomi daerah membawa perlunya akses masyarakat terhadap mekanisme pengisian jabatannya. Memang selama ini dapat dilalui dengan demokrasi perwakilan. Tetapi nilai demokrasi tersebut masih perlu dibuka luas lagi dalam demokrasi langsung pada pengisian jabatan politik. ${ }^{7}$

Gagasan demokratisasi pemerintahan dan pergulatan kedaulatan rakyat semakin mendapatkan tempat dengan adanya gagasan untuk pemilihan langsung pimpinan daerah. Gagasan pemilihan langsung kepala daerah inipun secara formal baru terealisasi pada 2004 dan baru dilaksanakan pada 2005. ${ }^{8}$ Semangat dilaksanakannya Pemilukada langsung adalah koreksi terhadap sistem demokrasi tidak langsung (perwakilan) di era sebelumnya, dimana Kepala Daerah dan Wakil Kepala Daerah dipilih oleh DPRD, menjadi demokrasi yang berakar langsung pada pilihan rakyat (pemilih). ${ }^{9}$

Undang-Undang Dasar (UUD 1945) Pasal 18 ayat (4) menegaskan bahwa “Gubernur, Bupati, dan Walikota masing-masing sebagai kepala pemerintahan Provinsi, Kabupaten, dan Kota dipilih secara demokratis". Rumusan pasal tersebut dapat ditarik beberapa kesimpulan bahwa: ${ }^{10}$ a) UUD 1945 tidak mengharuskan Kepala Daerah dipilih secara langsung, dan calon Kepala Daerah juga tidak harus berasal dari partai politik atau gabungan partai politik; b) frasa "dipilih secara demokratis" tidaklah dapat ditafsirkan bahwa rekrutmen pasangan calon menjadi kewenangan mutlak partai politik sebagai salah satu lembaga yang berfungsi

\footnotetext{
${ }^{6}$ Bagir Manan, Menyongsong Fajar Otonomi Daerah, Cet. III, FH UII Yogyakarta, 2004, hlm. 59.

${ }^{7}$ Muchamad Isnaeni Ramdhan, Kompedium Pemilihan Kepala Daerah (Pilkada), Badan Pembinaan Hukum Nasional Departemen Hukum dan HAM RI, Jakarta, 2009, hlm. 22.

${ }^{8}$ Retno Saraswati “Calon Perseorangan: Pergeseran Paradigma Kekuasaan Dalam Pemilukada”, dalam MasalahMasalah Hukum, Nomor 2 Jilid 40, April 2011, hlm. 196.

${ }^{9}$ Mustafa Lutfi, Hukum Sengketa Pemilukada di Indonesia Gagasan Perluasan Kewenangan Konstitusional Mabkamah Konstitusi, Cetakan Pertama, UII Press, Yogyakarta, 2010, hlm. 130. Melalui pemilihan kepala daerah secara langsung, amggota-anggota DPRD diharapkan tidak lagi menjual suaranya secara eceran kepada calon kepala daerah. Lihat Moh. Mahfud MD., Perdebatan Hukum Tata Negara Pasca Amandemen Konstitusi, Cetakan ke-2 RajaGrafindo Persada, Jakarta, 2011, hlm. 169.

${ }^{10}$ Suharizal, Pemilukada, Dinamika, dan Konsep Mendatang, Raja Grafindo Persada, Jakarta, 2011, hlm. 26.
} 
melakukan rekrutmen politik dalam pengisian jabatan publik melalui mekanisme yang demokratis; c) rumusan Pasal 18 ayat (4) UUD 1945 amandemen kedua dapat ditafsirkan sama dengan tata cara dan prosedural pemilu sebagaimana dinyatakan dalam beberapa pasal amendemen ketiga 2001. Artinya, pemilukada secara langsung, khususnya lembaga yang memiliki kewenangan melakukan rekrutmen calon Kepala Daerah adalah lembaga yang juga menjadi penanggung jawab pelaksanaan pemilu yaitu Komisi Pemilihan Umum; d) Pasal 18 ayat (4) hanya mengharuskan yang dipilih secara demokratis adalah Kepala Daerah (Gubernur, Bupati, dan Walikota). Dengan kata lain Wakil Kepala Daerah (Wakil gubernur, Wakil Bupati, dan Wakil Walikota) tidak harus dipilih satu paket dengan Kepala Daerah. Ketentuan ini juga dapat ditafsirkan bahwa posisi wakil kepala daerah sesungguhnya dapat dihilangkan dalam sistem pemerintahan daerah.

Jika kita menelaah risalah sidang MPR yang merumuskan Pasal 18 ayat (4) UUD 1945, para pembentuk undang-undang dasar memang menyepakati bahwa pemilihan Gubernur, Bupati, dan Walikota dilakukan dengan demokratis, tetapi di sisi lain adanya keinginan dari para pembentuk undang-undang dasar untuk memberi ruang bagi para pembentuk undang-undang agar mengatur pemilukada lebih lanjut sesuai dengan kondisi keragaman daerah dan situasi serta kondisi asalkan tidak bertentangan dengan prinsip demokrasi. ${ }^{11}$

Dalam risalah rapat panitia Ad Hoc I, pemikiran dari fraksi PPP yang melatar belakangi dicantumkannya frase "dipilih secara demokratis" antara lain sebagai berikut: “Gubernur, Bupati dan Walikota dipilih secara langsung oleh rakyat, yang selanjutnya diatur oleh Undang-Undang, hal ini sejalan dengan keinginan kita untuk pemilihan Presiden juga dipilih secara langsung".${ }^{12}$ “... Keempat, karena Presiden itu dipilih langsung, maka pada pemerintahan daerah pun Gubernur, Bupati, dan Walikota itu dipilih langsung oleh rakyat". ${ }^{13}$

Merujuk pada risalah rapat tersebut, dapat disimpulkan bahwa latar belakang dan maksud tujuan pembentuk Pasal 18 ayat (4) UUD 1945 adalah Gubernur, Bupati, dan Walikota dipilih secara demokratis adalah sama dengan pemilihan yang dilakukan terhadap Presiden. ${ }^{14}$

\footnotetext{
${ }^{11}$ Sekretariat Jenderal MPR RI,"Risalah Rapat Panitia Ad Hoc I (Sidang Tahunan 2000)", Buku kedua jilid 3C, 2000, hlm. 255. Dalam Cakra Arbas, Jalan Terjal Calon Independen pada Pemilukada di Provinsi Aceh, Jakarta, Sofmedia, 2012, hlm. 38.

${ }^{12}$ Ibid.

${ }^{13}$ Risalah Rapat... Ibid., hlm. 272.

${ }^{14}$ Cakra Arbas, Jalan Terjal... Op. Cit., hlm. 39.
} 
Penggunaan frase "dipilih secara demokratis" yang untuk kemudian ditafsirkan pemilukada secara langsung pernah dikuatkan oleh Mahkamah Konstitusi (MK) melalui Putusan No. 072-073/PUU-II/2004.

Menurut keterangan saksi Patrialis Akbar dan Lukman Hakim Saifuddin (Panitia Ad Hoc I MPR) yang membahas amandemen Pasal 18 UUD 1945, dalam persidangan judicial review UU No. 32 Tahun 2004 tentang Pemerintahan Daerah menjelaskan bahwa: ${ }^{15}$

"Latar belakang pemikiran rumusan Pasal 18 ayat (4) saat itu adalah bahwa sistem pemilihan yang akan diterapkan disesuaikan dengan perkembangan masyarakat. Masyarakat mempunyai pilihan apakah akan menerapkan sistem perwakilan (pemilihan dilakukan oleh DPRD) atau pemilihan dilakukan secara langsung (pemilihan dilakukan langsung oleh rakyat). Tujuannya adalah agar ada fleksibilitas bagi masyarakat dalam menentukan sistem pemilihan kepala daerah. Hal itu terkait erat dengan penghargaan konstitusi terhadap keragaman adat istiadat dan budaya masyarakat di berbagai daerah yang berbeda-beda. Baik sistem pemilihan secara langsung, maupun sistem pemilihan secara tidak langsung sama-sama masuk pada kategori sistem yang demokratis. Berdasarkan 2 (dua) pandangan ini, untuk kemudian disepakati menggunakan frasa "demokratis". Dalam artian karena pada ayat selanjutnya, yakni pada ayat (7) Pasal 18 UUD 1945 menyebutkan susunan dan tata cara penyelenggaraan pemerintahan daerah diatur dalam Undang-Undang, Undang-undanglah yang nantinya akan menentukan apakah pemilihan kepala daerah itu dilakukan secara langsung oleh rakyat atau sebagaimana sebelumnya dilakukan oleh DPRD, yang terpenting prinsip dasarnya adalah demokratis".

Putusan Mahkamah Konstitusi ini telah menafsirkan frasa 'dipilih secara demokratis" maksudnya adalah memberi kewenangan kepada pembuat UndangUndang untuk mempertimbangkan cara yang tepat dalam Pemilukada. Sekalipun pemilihan secara langsung telah diterapkan untuk memilih Presiden sebagaimana dirumuskan dalam Pasal 6A UUD 1945, hal ini tidak dapat diartikan bahwa pemilukada secara langsung menjadi satu-satunya cara untuk memaknai frasa “dipilih secara demokratis" yang dimuat dalam Pasal 18 ayat 4 UUD 1945. ${ }^{16}$

Menurut Taufiqurrahman Syahuri ${ }^{17}$ rumusan "dipilih secara demokratis" dalam ketentuan pemilukada juga mempertimbangkan pelaksanaan pemilukada di daerah-daerah yang bersifat khusus dan istimewa sebagaimana yang dimaksud Pasal 18B ayat (1) UUD 1045 yang berbunyi" Negara mengakui dan menghormati satuan-satuan pemerintahan daerah yang bersifat khusus atau bersifat istimewa yang diatur dengan Undang-Undang".

\footnotetext{
${ }^{15}$ Putusan Mahkamah Konstitusi No.072-073/PUU-II-2004, hlm. 31.

${ }^{16}$ Ibid., hlm. 38.
} 
Menurut Suharizal, ${ }^{18}$ maksud dan tujuan pembentukan Pasal 18 ayat (4) UUD 1945 yang mengatur bahwa Gubernur, Bupati, dan Walikota dipilih secara demokratis adalah tidak harus sama dan dapat juga disamakan dengan pemilihan yang dilakukan terhadap Presiden dan Wakil Presiden. Maka pengertian dipilih secara demokratis dapat ditafsirkan sama dengan tata cara pemilihan yang dilakukan terhadap Presiden dan Wakil Presiden seperti yang tercantum dalam BAB VIIB Pasal 22E UUD 1945 tentang Pemilihan Umum.

Meskipun UUD 1945 hanya menyebut pemilihan kepala daerah dipilih secara demokratis, pembentuk Undang-Undang akhirnya menyejajarkan tata cara pengisian kepala daerah dengan pemilihan presiden dan wakil presiden. Karena itu, makna "dipilih secara demokratis" dipersempit menjadi dipilih secara langsung.

Beberapa pertimbangan penting penyelenggaraan Pilkada langsung adalah sebagai berikut; Pertama, Pilkada langsung merupakan jawaban atas tuntutan aspirasi rakyat karena Presiden dan Wakil Presiden, DPR, DPD, bahkan Kepala Desa selama ini telah dilakukan secara langsung. Tuntutan masyarakat menjadi bagian penting yang harus diakomodasikan untuk memilih sendiri sesuai dengan aspirasinya, seorang kepala daerah yang benar-benar sesuai dan bisa memimpin daerahnya. Kedua, Pilkada langsung merupakan perwujudan UUD 1945. Seperti diamanatkan Pasal 18 ayat (4) UUD 1945, Gubernur, Bupati dan Walikota, masing-masing sebagai kepala pemerintahan daerah provinsi, kabupaten, dan kota dipilih secara demokratis. Ketiga, Pilkada langsung dipandang sebagai sarana pembelajaran demokrasi (politik) bagi rakyat (civics education). Keempat, Pilkada langsung dipandang sebagai sarana untuk memperkuat otonomi daerah. Keberhasilan otonomi daerah salah satunya ditentukan oleh pemimpin lokal. Semakin baik pemimpin lokal yang dihasilkan melalui Pilkada, maka komitmen pemimpin lokal untuk meningkatkan masyarakat yang menjadi tujuan otonomi daerah dapat diwujudkan. Kelima, Pilkada langsung merupakan sarana penting bagi proses kaderisasi kepemimpinan nasional. ${ }^{19}$

Di era reformasi ini kita menerapkan pemilihan Presiden dan Kepala Daerah secara langsung oleh rakyat. Pada pemilihan kepala daerah, banyak sekali catatan hitam yang mewarnai proses Pilkada, mulai dari money politics hingga bentrok antar-

\footnotetext{
${ }^{17}$ Taufiqurrahman Syahuri," Anatomi Putusan MK RI tentang Pemilukada”, Seminar Putusan MK Pengujian UU No. 32 Tahun 2004 tentang Pemerintahan Daerah, hlm. 6. Dalam Cakra Arbas, Jalan Terjal....Op. Cit., hlm. 41.

${ }^{18}$ Suharizal, Pemilukada, Dinamika, dan ...Op. Cit. hlm. 33.

${ }^{19}$ Samsul Wahidin, Hukum Pemerintahan Daerah Mengawasi Pemiliban Umum Kepala Daerah, Cetakan 1, Pustaka Pelajar, Yogyakarta, 2008, hlm. 139-141. Lihat juga Morison, Hukum Tata Negara Era Reformasi, Ramdina Prakarsa, Jakarta, 2005, hlm. 199-200.
} 
pendukung yang memakan banyak korban jiwa. Tidak heran jika kini banyak pihak yang menggugat sistem Pilkada agar sistem pemilihan langsung semacam itu ditinjau ulang. Pilkada langsung yang 'mahal' ini bukanlah demokrasi ideal yang kita impikan bersama. Pilkada langsung dengan cara politik uang sebenarnya tidak lebih dari sebuah 'demokrasi teatrikal', pseudo demokrasi atau facade democracy yang tidak banyak manfaatnya karena tidak berkualitas dan tidak banyak bermanfaat untuk perbaikan bangsa ke depan. ${ }^{20}$ Mestinya, ketika demokrasi berjalan pascaotoritarianisme, maka ia 'harus' dan bahkan 'wajib' memberikan kesejahteraan atau kebaikan bersama dengan serta merta kepada warga masyarakat.

Kecenderungan masyarakat untuk mengapresiasi pelaksanaan pemilukada juga semakin menurun. Dalam berbagai penelitian, ${ }^{21}$ ditemukan fakta mengenai antusiasme masyarakat terhadap proses dan hasil Pemilukada yang cenderung semakin berkurang atau menurun. Meskipun tidak ada ukuran pasti mengenai berapa persen jumlah partisipasi masyarakat agar Pemilukada dikatakan tinggi tetapi fakta penurunan partisipasi masyarakat menunjukkan adanya persoalan dalam penyelenggaraan Pemilukada.

Terdapat sekurang-kurangnya 4 (empat) penyebab menurunnya partisipasi masyarakat dalam Pemilukada. Pertama ${ }^{22}$ masyarakat secara sadar memang tidak mau menggunakan hak pilihnya karena dilandasi oleh sikap apatis. Bagi mereka, menggunakan atau tidak menggunakan hak suara dalam Pemilukada maknanya sama: tidak memberi pengaruh signifikan dalam keseharian hidup. Kedua, Daftar Pemilih Tetap (DPT) yang amburadul dan tidak akurat berkontribusi besar melemahkan semangat masyarakat yang semula berniat untuk berpartisipasi. Ketiga, masyarakat pemilih cenderung lebih mendahulukan kebutuhan individualnya, seperti bekerja, berladang, merantau atau sekolah ketimbang hadir ke TPS untuk menggunakan hak pilihnya. Keempat, partisipasi dalam pemilukada didorong semangat pragmatisme masyarakat. Kalau ada kandidat yang memberi keuntungan mereka mau berpartisipasi, kalau tidak maka tidak perlu berpartisipasi.

Menyikapi pelaksanaan pemilihan Kepala Daerah (Pilkada) langsung yang semakin banyak mendapat sorotan dari berbagai kalangan, kini DPR berupaya

\footnotetext{
${ }^{20}$ http://www.pewarta-kabarindonesia.blogspot.com. Di akses tanggal 2 Januari 2013.

${ }_{21}$ Moh. Mahfud MD, "Evaluasi Pemilukada Dalam Perspektif Demokrasi dan Hukum” Ceramah Kunci dalam Seminar Nasional Evaluasi Pemilukada: Antara Teori dan Praktik, diselenggarakan oleh Mahkamah Konstitusi pada Rabu-Kamis, 25-26 Januari 2012 di Hotel Sultan Jakarta, hlm. 26.

${ }^{22}$ Ibid.
} 
merevisi undang-undang Pilkada dan mencari masukan ke berbagai daerah. Isu utama yang berkembang adalah banyaknya dampak negatif Pilkada langsung, antara lain politik uang, konflik sosial, dan keberpihakan penyelenggara. Akhirnya, Pilkada langsung menghasilkan kepala daerah yang korup dan pemerintah bayangan (shadow government) oleh tim sukses, yang justru lebih berkuasa. Lalu timbul pertanyaan, apa yang salah dari Pilkada langsung? Apakah budaya politiknya, desain, atau teknis penyelenggaraan? Pilkada langsung diadopsi dari masyarakat yang menerapkan demokrasi liberal yang mensyaratkan adanya kebebasan memilih. Memilih adalah hak individu, bukan kewajiban. Pilkada langsung bersifat kompetitif dan fair. Apakah kondisi masyarakat kita memenuhi persyaratan itu? ${ }^{23}$

Sedangkan Nahdlatul Ulama (NU) menilai pemilihan kepala daerah secara langsung sebagai hasil reformasi yang diharapkan membawa kebaikan ternyata di dalam praktiknya banyak menimbulkan kerusakan sehingga patut dipertimbangkan untuk dihentikan. ${ }^{24}$

Untuk itu, Musyawarah Nasional (Munas) Alim Ulama dan Konferensi Besar (Konbes) Nahdlatul Ulama (NU) merekomendasikan penghapusan pilkada langsung, baik untuk memilih Gubernur maupun Bupati/Wali Kota. Rekomendasi tersebut merupakan hasil sidang Komisi B atau Bahtsul Masail Ad-Diniyah Maudlu'iyyah yang dipimpin oleh KH Hartami Hasni di Pondok Pesantren Kempek, Kecamatan Gempol, Kabupaten Cirebon, Jawa Barat. Dengan hasil pembahasan ini, NU secara resmi akan merekomendasikan agar pilkada kembali dilaksanakan secara tidak langsung melalui DPRD. ${ }^{25}$

NU berpendapat agar Pilkada langsung ditinjau ulang, dan kembali ke Pilkada tidak langsung oleh DPRD. Selain pilkada langsung tidak sesuai dengan Pancasila, kerugian yang ditimbulkan jauh lebih besar dibandingkan dengan kemaslahatan yang diperoleh. Melalui Pilkada langsung diharapkan terpilih pemimpin yang aspiratif dan lebih bisa menyejahterakan rakyat. Namun, fakta di lapangan menunjukkan Pilkada langsung justru menimbulkan banyak kerugian seperti maraknya politik uang yang merusak moral, menyedot biaya besar, dan

\footnotetext{
${ }^{23}$ http://www.metro7.co.id . Solusi Pilkada Langsung.html. Di akses tanggal 3Januari 2013. Ada banyak masalah yang bisa diidentifikasi selama proses pemilihan kepala daerah, selengkapnya baca Leo Agustina, Pilkada dan Dinamika Politik Lokal, Cetakan I, Pustaka Pelajar, Yogyakarta, 2009, hlm. 121-152.

${ }^{24}$ Faizal Rizki http://www.aktual.co/politik. Nu menilai pilkada langsung lebih baik ditiadakan.Diakses tanggal 4 Januari 2013.

${ }^{25}$ http://www.seputar-indonesia.com. Diakses tanggal 7 Januari 2013.
} 
menimbulkan konflik horizontal. Jadi kemaslahatan yang diharapkan dari pilkada langsung masih angan-angan, sementara kerugian yang ditimbulkan sudah terbukti. $^{26}$

Tetapi, reaksi terhadap wacana pemilihan kepala daerah oleh DPRD terus bermunculan. Di antaranya Direktur Eksekutif Perkumpulan untuk Pemilu dan Demokrasi (Perludem) Titi Anggraini mengatakan bahwa, wacana tersebut adalah wacana yang mengingkari semangat dan tujuan besar proses demokratisasi di Indonesia, yaitu meningkatkan keterlibatan dan partisipasi masyarakat sebesarbesarnya, menguatkan transparansi proses politik dan ketatanegaraan. Alasan mahalnya ongkos politik penyelenggaraan pemilukada adalah alasan yang tidak bisa menjustifikasi pemilihan gubernur oleh DPRD. Belum ada penelitian ilmiah yang bisa memastikan bahwa biaya pemilihan gubernur oleh DPRD jauh lebih efisien dari pada pemilukada langsung. Tidak ada yang bisa menjamin bahwa ongkos politik 'tidak resmi' untuk 'membeli perahu' partai di DPRD jauh lebih sedikit ketimbang penyelenggaraan pemilihan langsung oleh rakyat. ${ }^{27}$

Sistem yang dihasilkan era reformasi ini terbukti menimbulkan kerusakan dan patut untuk dihentikan. Pendidikan politik dan demokrasi yang diperoleh masyarakat bukanlah pendidikan yang baik dan bermoral, melainkan justru pendidikan yang tidak sehat, dimana pemilihan langsung diharapkan memunculkan pemimpin-pemimpin yang berkualitas namun kenyataannya malah sebaliknya, karena sistem ini memunculkan cara-cara kapitalis yang transaksional sehingga tidak akan terjadi hubungan yang sinergis antara Rakyat dengan Pemimpin. Pemimpin yang dihasilkan oleh sistem pemilihan secara langsung tidak akan bertanggung jawab terhadap rakyat karena mereka merasa telah membeli suara Rakyat dan rakyat tidak bisa melakukan kontrol sosial karena mereka sudah menggadaikan idealisme nya, kondisi ini sangat bahaya bagi kehidupan berbangsa dan bernegara. Pemilihan secara langsung banyak menimbulkan "kemadlorotan" atau kerugian di dalam pelaksanaannya seperti konflik sosial, memecah belah kerukunan keluarga, mengakibatkan suap dan berujung korupsi, sehingga tanpa mengurangi arti demokrasi, Pemilihan langsung sudah saatnya dihentikan dan pimpinan daerah dipilih para wakil rakyat, dengan demikian rakyat bisa bekerja lebih produktif tanpa

\footnotetext{
${ }^{26}$ Ibid.

${ }^{27}$ http://news.detik.com.langkah mundur jika pemilihan kepala daerah kembali ke tangan dprd. Diakses tanggal 10 Januari 2013.
} 
disibukkan oleh pemilihan langsung yang banyak memakan korban dan jelas-jelas bertentangan dengan demokrasi Pancasila. ${ }^{28}$

\section{Dewan Kehormatan Penyelenggara Pemilu}

Berbeda dengan UU No. 22 Tahun 2007 yang memberikan wewenang kepada KPU untuk memeriksa pengaduan dan/atau laporan adanya pelanggaran kode etik yang dilakukan oleh anggota KPU, KPU Provinsi, PPLN, dan KPPSLN, dalam UU No. 15 Tahun 2011 wewenang tersebut dihapus. Kemudian melalui UU No. 15 Tahun 2015 dibentuk lembaga baru yaitu Dewan Kehormatan Penyelenggara Pemilu, selanjutnya disingkat DKPP yang berdiri pada Juni 2012, adalah lembaga yang bertugas menangani pelanggaran kode etik Penyelenggara Pemilu dan merupakan satu kesatuan fungsi penyelenggaraan Pemilu. ${ }^{29}$

UU No. 15 Tahun 2011 Pasal 109 menyatakan bahwa, DKPP bersifat tetap dan berkedudukan di ibu kota negara. ${ }^{30} \mathrm{DKPP}$ dibentuk untuk memeriksa dan memutuskan pengaduan dan/atau laporan adanya dugaan pelanggaran kode etik yang dilakukan oleh anggota KPU, anggota KPU Provinsi, anggota KPU Kabupaten/Kota, anggota PPK, anggota PPS, anggota PPLN, anggota KPPS, anggota KPPSLN, anggota Bawaslu, anggota Bawaslu Provinsi dan anggota Panwaslu Kabupaten/Kota, anggota Panwaslu Kecamatan, anggota Pengawas Pemilu Lapangan dan anggota Pengawas Pemilu Luar Negeri. DKPP terdiri dari: a. 1 (satu) orang unsur KPU; b. 1 (satu) orang unsur Bawaslu; c. 1 (satu) orang utusan masing-masing partai politik yang ada di DPR; d. 1 (satu) orang utusan Pemerintah; e. 4 (empat) orang tokoh masyarakat dalam hal jumlah utusan partai politik yang ada di DPR berjumlah ganjil atau 5 (lima) orang tokoh masyarakat dalam hal jumlah utusan partai politik yang ada di DPR berjumlah genap. Masa tugas keanggotaan DKPP adalah 5 (lima) tahun dan berakhir pada saat dilantiknya anggota DKPP yang baru. Pembentukan DKPP ditetapkan dengan Keputusan Presiden.

Tugas DKPP meliputi: a. menerima pengaduan dan/atau laporan dugaan adanya pelanggaran kode etik oleh Penyelenggara Pemilu; b. melakukan

${ }^{28}$ Ibid.

${ }^{29}$ Menurut UU No. 22 Tahun 2007, untuk memeriksa pengaduan dan/atau laporan adanya dugaan pelanggaran kode etik yang dilakukan oleh anggota KPU dan anggota KPU Provinsi, dibentuk Dewan Kehormatan KPU yang bersifat ad hoc dan ditetapkan dengan keputusan KPU. Dewan Kehormatan KPU berjumlah 5 (lima) orang yang terdiri atas 3 (tiga) orang anggota KPU dan 2 (dua) orang dari luar anggota KPU.

${ }^{30}$ Pasal 111 (1) UU No 22 Tahun 2007 ditegaskan bahwa, untuk memeriksa pengaduan dan/atau laporan adanya dugaan pelanggaran kode etik yang dilakukan oleh anggota KPU dan anggota KPU Provinsi, dibentuk Dewan Kehormatan KPU yang bersifat ad hoc yang ditetapkan dengan keputusan KPU. 
penyelidikan dan verifikasi, serta pemeriksaan atas pengaduan dan/atau laporan dugaan adanya pelanggaran kode etik oleh Penyelenggara Pemilu; c. menetapkan putusan; dan d. menyampaikan putusan kepada pihak-pihak terkait untuk ditindaklanjuti.

DKPP mempunyai wewenang untuk: a. memanggil Penyelenggara Pemilu yang diduga melakukan pelanggaran kode etik untuk memberikan penjelasan dan pembelaan; b. memanggil pelapor, saksi, dan/atau pihak-pihak lain yang terkait untuk dimintai keterangan, termasuk untuk dimintai dokumen atau bukti lain; dan c. memberikan sanksi kepada Penyelenggara Pemilu yang terbukti melanggar kode etik.

Lembaga yang dibentuk pada Juni 2012 ini telah memberhentikan 70 anggota KPU dan Bawaslu karena melanggar kode etik. ${ }^{31}$ Di kabupaten Sinjai misalnya, DKPP telah memberhentikan 5 (lima) anggota KPUD karena kelima komisioner tersebut dianggap melakukan kesalahan saat tahapan Pilkada Sinjai, yakni ketika komisioner meloloskan pasangan calon yang rekomendasinya bermasalah. Selain itu, KPU Sinjai juga menggugurkan kandidat tertentu tanpa melakukan klarifikasi ke pengurus pusat partai politik yang mengusung. ${ }^{32}$ Tiga anggota Komisi Pemilihan Umum (KPU) Kota Gorontalo juga diberhentikan. Dewan Kehormatan Penyelenggara Pemilu (DKPP) menilai mereka tidak netral dan memihak ke salah satu pasangan calon Wali Kota Gorontalo. DKPP menilai mereka sengaja meloloskan pasangan calon yang tidak memenuhi syarat. ${ }^{33}$

\section{Pertimbangan Dewan Kehormatan Pemilu terhadap Gugatan Khofifah-Herman}

Dewan Kehormatan Penyelenggara Pemilu (DKPP) memberhentikan sementara tiga komisioner KPU Jawa Timur atas gugatan pasangan Khofifah-Herman. Menurut keterangan majelis DKPP Saut Sitomurang, ${ }^{34}$ pertimbangan DKPP memberhentikan sementara tiga komisioner KPU Jawa Timur Karena berdasarkan fakta persidangan, dukungan pasangan Berkah adalah sah dari Partai Kedaulatan (PK) dan Partai Persatuan Nahdlatul Ummah Indonesia (PPNUI). Tindakan teradu (KPU) yang

\footnotetext{
${ }^{31}$ http://www.hukumonline.com.dkpp -70 anggota kpu bawaslu diberhentikan. Diakses tanggal 7 Juni 2013.

${ }^{32}$ http://m.koran-sindo.com. Diakses tanggal 2 Juni 2013.

${ }^{33}$ http://www.metrotvnews.com/metronews."Anggota KPU Gorontalo Diberhentikan karena tak Netral." Diakses tanggal 4 Juni 2013.

${ }^{34}$ http://news.detik.com.ini-pertimbangan-dkpp-nonaktifkan-3-komisioner-kpu-jatim? Diakses tanggal 20 Oktober 2013.
} 
menyebut tidak memenuhi syarat adalah bertentangan dengan peraturan perundangan. Menurutnya, KPU terbukti menghilangkan hak konstitusional partai untuk mengusulkan calon dalam Pemilu Kada Jatim termasuk kepada pasangan Khofifah-Herman sebagai cagub dan cawagub. Pertimbangan lainnya, adanya pernyataan komisioner KPU di beberapa media membuktikan KPU tidak netral dan berpihak yaitu di Metro TV dan koran Jawa Pos.

Ada enam poin yang dibacakan oleh DKPP dalam sidang pembacaan amar putusan dengan materi gugatan Khofiffah-Herman ke Komisi Pemilihan Umum Jawa Timur, melalui Keputusan DKPP N0.74/DKPP-PKE-II/2013 yaitu sebagai berikut: 1. DKPP mengabulkan gugatan yang diajukan pengadu; 2. Menjatuhkan sanksi peringatan kepada Ketua KPU Jatim Andre Dewanto; 3. Merehabilitasi nama Komisiner KPU Jatim Sayekti dari semua tuduhan; 4. Sanksi pemberhentian sementara kepada tiga Komisioner KPU Jatim, yakni Agung Nugroho, Agus Fauzi, dan Nadjib Hamid; 5. DKPP memerintahkan KPU RI meninjau keputusan KPU Jatim yang tidak meloloskan Khofiffah-Herman. Dan memulihkan hak konstitusional Khofiffah-Herman; 6. DKPP memerintahkan Bawaslu mengawasi hal tersebut.

Seperti yang pernah dilakukan oleh Mahkamah Konstitusi (MK), sebagai lembaga penyelesai sengketa pemilu putusan DKPP ini seakan mengulangi kejadian yang sama, yaitu melakukan semacam 'penerobosan kewenangan'. Jika pada 2008 MK dianggap menerobos kewenangannya karena memerintahkan pemungutan suara ulang, maka pada 2013 ini DKPP yang kewenangan aslinya hanya menilai pelanggaran kode etik penyelenggara pemilu dapat menerbitkan putusan yang isinya memerintahkan pelolosan pasangan tertentu. Pelolosan Khofifah - Herman oleh putusan DKPP ini kemudian membuat Khofifah - Herman mencabut gugatannya di PTUN karena merasa perkara mereka sudah selesai dan tidak perlu dilanjutkan karena DKPP sudah memerintahkan KPUD untuk mengikutkan pasangan Khofifah - Herman pada Pilgub Jatim 2013.

Pada waktu itu beredar isu bahwa penyebab sebenarnya terjadinya dualisme dukungan itu adalah karena oknum dari partai Kedaulatan dan PPNUI diberi uang oleh pasangan tertentu (KARSA) agar mengalihkan dukungannya ke pasangan KARSA. Sementara ketua umum partai sebenarnya menyatakan mendukung pasangan BERKAH. Temuan ini dikemukakan oleh saksi dalam sidang DKPP yang menyebutkan bahwa mereka menyaksikan para beberapa petinggi parpol dikumpulkan oleh tim sukses KARSA dan diarahkan untuk memberikan dukungan 
kepada KARSA. Pasangan KARSA disebut-sebut dalam pertemuan itu membagibagikan sejumlah uang pada petinggi parpol tersebut, namun ketua umum PK yang hadir disitu menolak tawaran itu. Ketua umum PPNUI yang mendukung BERKAH juga merasa tanda tangannya dipalsukan sehingga ada surat dukungan palsu untuk pasangan KARSA. Diduga peristiwa dualisme dukungan PK dan PPNUI ada kaitannya dengan peristiwa bagi-bagi duit itu. Dugaan politik uang ini tentu perlu didalami lagi dan divalidasi lagi kebenarannya oleh pihak yang berwenang, dalam hal ini Panwaslu dan kepolisian, agar pasangan yang terpilih nantinya betul-betul pasangan yang berkompetisi secara bersih, bukan pasangan yang melakukan serangkaian pelanggaran pemilu termasuk politik uang. ${ }^{35}$

Menyikapi keputusan DKPP tersebut Pakar Hukum Tata Negara Yusril Ihza Mahendra, menegaskan bahwa Keputusan DKPP N0.74/DKPP-PKE-II/2013 itu jelas-jelas melanggar hukum tata negara. Pembatalan keputusan KPU hanya menjadi hak dari Pengadilan Tata Usaha Negara (PTUN). Sebab keputusan KPU merupakan fakta hukum yang hanya bisa dibatalkan oleh PTUN sebagai lembaga hukum. Sedangkan DKPP merupakan salah satu lembaga penyelenggara Pemilu, yang hanya bertugas untuk mengawasi dan mensidangkan pelanggaran kode etik penyelenggara Pemilu. Sekalipun DKPP menyatakan sesuai fakta, bahwa anggota KPU Jatim terbukti melakukan pelanggaran etika. DKPP tetap tidak bisa langsung membatalkan keputusan yang sudah dibuat. Keputusan DKPP itu hanya bisa dibawa dan dijadikan bukti dalam persidangan di PTUN. DKPP banyak melanggar hukum tata negara. ${ }^{36}$

Sedangkan pakar Komunikasi Politik dari Unair, Suko Widodo menilai, putusan DKPP yang meloloskan Khofifah-Herman sebagai peserta Pilgub, yang langsung diamini oleh KPU RI sebagai ketidak-wajaran. Seharusnya KPU Pusat, mempelajari terlebih dulu detail problem yang terjadi di Jawa Timur dan mendengar masukan dari berbagai pihak. Jika KPU menuruti DKPP, independensi KPU patut dipertanyakan. Keadaan ini berpotensi menggoda rasa keadilan masyarakat Jawa Timur.

Sementara itu, Cagub Jatim dari jalur independen, Eggi Sudjana ikut mengkritisi keputusan DKPP itu telah melampaui batas kewenangan. DKPP telah melakukan intervensi untuk meloloskan pasangan BerKah yang dicoret KPU Jatim

${ }^{35}$ http:/ / ekhopratama.wordpress.com. Catatan tentang pilgub jatim 2013. Diakses tanggal 2 Oktober 2013.

${ }^{36} \mathrm{http}: / /$ www.sapujagatnews.com/yusril-dkpp-langgar-hukum-tata-negara-serie-2.Diakses tanggal 4 Desember 2013. 
karena tidak mampu mengumpulkan dukungan minimal 15\% sebagaimana aturan pencalonan Pilgub.

Berbeda dengan mantan Ketua Mahkamah Konstitusi, Mahfud MD yang mengatakan apa yang dilakukan DKPP sudah tepat. Termasuk dengan menonaktifkan tiga komisioner KPU Jawa Timur. Menurut Mahfud MD, demokrasi yang harus dibangun di negara ini adalah demokrasi yang terhormat, demokrasi yang melindungi hak konstitusional warga negara, demokrasi yang memungkinkan terjadinya persaingan secara sehat, adil, jujur, dan bermartabat. Demokrasi harus bersih, jangan dibunuh dari hulunya, ibarat membunuh bayi yang belum lahir. Kalau pembunuhan demokrasi dari hulu dengan permainan formalitas, semua harus melawan hal seperti itu, karena demokrasi yang kita bangun adalah demokrasi yang terhormat. Karena itu, DKPP harus tegas terhadap praktik pembunuhan demokrasi. DKPP mengadili persoalan etika, sedangkan hukum merupakan kristalisasi etika. Jika etika dilanggar sedemikian rupa sehingga substansinya hilang, yakni melindungi hak konstitusional, maka etika harus diutamakan, karena aturan merupakan produk etika. Yang diutamakan bukan aturannya, tapi etikanya. ${ }^{37}$

\section{Alasan Mengajukan Gugatan Hasil Pemilukada ke MK}

Khofifah Indar Parawansa-Herman Suryadi Sumawiredja (Pemohon) mengajukan permohonan keberatan terhadap Keputusan Termohon No. 23/Kpts/ KPU-Prov-014/2013 tertanggal 07 September 2013 tentang Penetapan Hasil Rekapitulasi Penghitungan Suara Tingkat Provinsi Oleh KPU Provinsi Jawa Timur dalam Pemilihan Umum Kepala Daerah dan Wakil Kepala Daerah Provinsi Jawa Tahun 2013 dan Nomor 24/Kpts/KPU-Prov-014/2013 tertanggal 07 September 2013 tentang Penetapan Pasangan Calon Kepala Daerah dan Wakil Kepala Daerah Terpilih Dalam Pemilihan Umum Kepala Daerah dan Wakil Kepala Daerah Provinsi Jawa Timur 2013.

Keberatan tersebut di atas didasarkan pada fakta bahwa telah terjadi berbagai pelanggaran serius, baik pelanggaran yang bersifat administrasi maupun pelanggaran pidana, secara sistematis, terstruktur, dan masif "merata", sehingga secara langsung mempengaruhi hasil perolehan suara yang telah ditetapkan termohon (KPU Provinsi Jawa Timur) yang memenangkan Pasangan Calon Nomor Urut 1.

\footnotetext{
2013.

${ }^{37}$ http://khofifahcenter.com.mahfud-md-dkpp-bisa-batalkan-putusan-kpu-jatim. Diakses tanggal 4 desember
} 
Pemohon mengatakan bahwa, jenis pelanggaran yang bersifat sistematis yaitu calon petahana telah memanfaatkan posisinya untuk menggunakan dan memanfaatkan Anggaran Pendapatan dan Belanja Daerah (APBD) dan aparatur negara/pejabat untuk memenangkan dirinya dalam Pemilukada Provinsi Jawa Timur Tahun 2013. ${ }^{38}$

Secara terstruktur melalui dan melibatkan pejabat struktural dan aparatur pemerintahan daerah dari tingkatan kepala dinas hingga tingkatan desa, termasuk melibatkan anggota DPRD Provinsi Jawa Timur,baik dalam bentuk pembagian uang tunai berupa bantuan keuangan kepada kepala desa, kelompok masyarakat, madratsah dinniyah (Madin) dan atau pemberian bantuan barang, di samping itu melibatkan Termohon selaku Penyelenggara Pemilukada. Hal ini dapat dilihat dari "penjegalan" terhadap Pemohon untuk menjadi pasangan calon Kepala Daerah dan Wakil Kepala Daerah Yang Memenuhi Syarat dalam Pemilukada Provinsi Jawa Timur Tahun 2013. ${ }^{39}$

Sedangkan pelanggaran secara masif diawali oleh calon petahana dan juga oleh Termohon selaku penyelenggara Pemilukada sampai tingkatan paling bawah (KPPS) dalam bentuk pemanfaatan dana hibah dan bansos berjumlah Rp. 5.065.518.000.000,yang penyalurannya tidak sah. Pelanggaran yang bersifat masif "merata" tersebut, berupa pembagian uang yang diambilkan dari program yang didanai APBD kepada pemilih secara merata di seluruh wilayah kabupaten dan kota se-Jawa Timur dengan arahan untuk memilih Pasangan Calon Nomor Urut $1 .^{40}$

Pelanggaran yang dilakukan oleh Penyelenggara Pemilu menurut Pemohonsebagai berikut: ${ }^{41}$

\begin{tabular}{|c|c|c|c|}
\hline N0 & Jenis Pelanggaran & Tempat & Waktu \\
\hline 1 & $\begin{array}{l}\text { Kesengajaan Termohon yang tidak meloloskan } \\
\text { Pemohon sebagai Pasangan Calon Gubernur dan } \\
\text { Wakil Gubernur JawaTimur sehingga } \\
\text { penetapannya harus dilakukan oleh KPU }\end{array}$ & Surabaya & 14 Juli 2013 \\
\hline 2 & $\begin{array}{l}\text { Termohon tidak segera mensosialisasikan } \\
\text { penetapan Pemohon sebagai Pasangan Calon } \\
\text { Gubernur dan Wakil Gubernur awaTimur yang } \\
\text { memenuhi syarat dalam Pemilukada Jawa Timur } \\
\text { Tahun 2013, setelah adanya Penetapan dari } \\
\text { KPU,sehingga Pemohon sangat dirugikan. }\end{array}$ & Jakarta & 31 juli 2013 \\
\hline
\end{tabular}

\footnotetext{
${ }^{38}$ Putusan mahkamah Konstitusi Nomor 117/PHPU.D-XI/2013, hlm. 10.

${ }^{39}$ Ibid., hlm. 18.

${ }^{40}$ Ibid., hlm. 21.

${ }^{41}$ Ibid., hlm. 22.
} 


\begin{tabular}{|c|c|c|c|}
\hline N0 & Jenis Pelanggaran & Tempat & Waktu \\
\hline 3 & $\begin{array}{l}\text { Termohon tidak segera melakukan pencetakan } \\
\text { nama Pemohon dalam Formulir Model C-1 kwk } \\
\text { sebagaimana yang telah dilakukan Termohon } \\
\text { terhadap pasangan lain. (diskriminatif) }\end{array}$ & Surabaya & $\begin{array}{l}10 \text { Agustus } \\
2013\end{array}$ \\
\hline 4 & $\begin{array}{l}\text { Banyak KPPS yang tidak dilantik sebelum } \\
\text { menjalankan tugas (hampir seluruh KPPS di } \\
\text { Kabupaten Tulungagung) }\end{array}$ & Tulungagung & Agustus 2013 \\
\hline 5 & $\begin{array}{l}\text { Adanya keterlambatan pemberian/penetapan } \\
\text { DPT oleh Termohon dan baru diterima oleh } \\
\text { Pemohon pada tanggal } 28 \text { Agustus 2013, padahal } \\
\text { seharusnya paling lambat tanggal; 24Agustus } 2013 \\
\text { serta akurasi DPT sangat diragukan. }\end{array}$ & Surabaya & $\begin{array}{l}28 \text { Agustus } \\
2013\end{array}$ \\
\hline 6 & $\begin{array}{l}\text { Banyaknya kecurangan dan permasalahan yang } \\
\text { dilakukan oleh KPPS yang tecermin dalam laporan } \\
\text { Formulir Model C-1 }\end{array}$ & $\begin{array}{l}\text { Di } \quad 21 \\
\text { Kabupaten } / \\
\text { Kota }\end{array}$ & $\begin{array}{l}29 \text { Agustus } \\
2013\end{array}$ \\
\hline 7 & $\begin{array}{l}\text { Banyaknya masyarakat/pendukung pemohon } \\
\text { yang tidak mendapatkan Formulir Model C-6/ } \\
\text { undangan untuk mencoblos di TPS dan atau } \\
\text { dihilangkan hak suaranya }\end{array}$ & $\begin{array}{l}\text { Di Kabupaten } \\
\text { S a m p a } \mathrm{g}, \\
\text { Bangkalan, } \\
\text { Pasuruan }\end{array}$ & $\begin{array}{l}29 \text { Agustus } \\
2013\end{array}$ \\
\hline 8 & $\begin{array}{l}\text { Termohon mencetak surat suara melebihi jumlah } \\
\text { DPT ditambah } 2.5 \% \text {-nya yang seharusnya } \\
30.785 .105 \text { surat suarasebagaimana disyaratkan } \\
\text { Undang-Undang, namun mencetak surat suara } \\
\text { sebanyak } 33.362 .095 \text { surat suara ada tambahan } \\
+10 \% \text { dari DPT }\end{array}$ & Bandung & 31 Juli 2013 \\
\hline 9 & $\begin{array}{l}\text { Termohon tidak mentaati standar penngadaan } \\
\text { barang dan jasa yang disyaratkan oleh peraturan } \\
\text { perundang-undangan, berdasarkan dokumen } \\
\text { lelang Formulir Model C-1 kwk.kpu yang } \\
\text { seharusnya dicetak menggunakan security paper } \\
\text { yang dilengkapi oleh hologram/microtex, pada } \\
\text { kenyataannyayang dicetak bukan security paper, } \\
\text { sehingga dokumen formulir Model C-1 kwk.kpu } \\
\text { dalam Pemilukada a quomerupakan dokumen } \\
\text { tidak sah, karena dapat diperbanyak dengan oleh } \\
\text { siapapun dan sangat berpotensi } \\
\text { menimbulkankecurangan/pelanggaran }\end{array}$ & Surabaya & Juli 2013 \\
\hline 10 & $\begin{array}{l}\text { Seluruh warga di TPS sesuai DPT tidak mendapat } \\
\text { undangan C-6/ke TPS untuk pencoblosan, namun } \\
\text { semua surat suaratersebut, dicoblos sendiri oleh } \\
\text { petugas TPS.(Pencoblosan surat suara borongan) }\end{array}$ & Bangkalan & $\begin{array}{l}29 \text { Agustus } \\
2013\end{array}$ \\
\hline
\end{tabular}

Dalam hal ini pemohon juga mengajukan saksi ahli antara lain Tjipta Lesmana yang mengatakan bahwa Penggelembungan jumlah APBD Jawa Timur dari Rp. 827.000.000,00 pada tahun 2010 hingga Rp. 5 Triliun untuk APBD 2013. Untuk itu, Mahkamah Konstitusi tidak ragu sedikit pun terhadap kebenaran bukti bukti kecurangan yang sistematis dan merata dalam Pemilukada Gubernur Jawa Timur dan menyatakan Pasangan Calon Nomor Urut 1 disqualified alias didiskualifikasi 
dalam Pemilukada menyatakan Pasangan Calon Nomor Urut 1 disqualified alias didiskualifikasi dalam Pemilukada. ${ }^{42}$

Sedangkan Riza Ramli mengatakan bahwa dengan sengaja pasangan calon nomor urut 1 melakukan politik kartel, yaitu mencegah lawannya yang potensial untuk menang. Maruarar Siahaan menyimpulkan dari apa yang disebutkan Pemohon dan kuasanya tersimpul ada kejahatan Pemilukada dan korupsi. Kalau itu benar dan penilaian akan terserah kepada Majelis Hakim, maka keputusan KPU Jatim tentang rekapitulasi penghitungan suara penetapan pasangan calon terpilih batal demi hukum. ${ }^{43}$

\section{Pendapat Mahkamah}

Setelah Mahkamah memeriksa dan mencermati secara saksama dalil Pemohon dan keterangan Pihak Terkait, serta bukti-bukti Pemohon dan Pihak Terkait, Mahkamah menemukan hal-hal sebagai sebagai berikut:

1) Bahwa Pemerintahan Provinsi Jawa Timur menetapkan Peraturan Daerah Provinsi Jawa Timur Nomor 13 Tahun 2012 tentang Anggaran Pendapatan dan Belanja Daerah Provinsi Jawa Timur Tahun Anggaran 2013. 2) Bahwa Gubernur Jawa Timur menetapkan Peraturan Gubernur Provinsi Jawa Timur Nomor 78 Tahun 2012 tentang Penjabaran Anggaran Pendapatan dan Belanja Daerah Provinsi Jawa Timur Tahun Anggaran 2013. 3) Rencana Pembangunan Jangka Menengah Daerah (RPJMD) Tahun 2009- 2014 Pemerintah Provinsi Jawa Timur sebagai acuan resmi Pemerintah Daerah dan Dewan Perwakilan Rakyat Daerah Provinsi Jawa Timur dalam menentukan prioritas program tahunan.

Pengalokasian atau peningkatan jumlah pembelanjaan Pemerintah Daerah Provinsi Jawa Timur sejak tahun 2010 sampai dengan tahun 2013 sebagaimana tertuang dalam Peraturan Daerah Provinsi Jawa Timur Nomor 13 Tahun 2012 tentang Anggaran Pendapatan dan Belanja Daerah Provinsi Jawa Timur Tahun Anggaran 2013 dan Peraturan Gubernur Provinsi Jawa Timur Nomor 78 Tahun 2012 Penjabaran Anggaran Pendapatan dan Belanja Daerah Provinsi Jawa Timur Tahun Anggaran 2013, merupakan salah satu bentuk kewajiban Gubernur menyusun dokumen Rencana Pembangunan Jangka Menengah Daerah (RPJMD) untuk periode 5 (lima) tahun atau selama masa jabatan.

Gubernur wajib melaksanakan dokumen RPJMD untuk menyelesaikan permasalahan dan mengoptimalkan potensi daerah yang secara terencana dan bertahap melalui APBD dengan mengutamakan kewenangan yang wajib disusun sesuai dengan prioritas dan kebutuhan daerah. Terkait dengan Program Jalinkesra yang dilakukan oleh Pemerintah Daerah Provinsi Jawa Timur, menurut Mahkamah program tersebut merupakan program berkelanjutan yang dimulai dan dilaksanakan sejak tahun 2010. Penyusunan anggaran Program Jalinkesra

\footnotetext{
${ }^{42}$ Ibid., hlm. 33.

${ }^{43}$ Ibid., hlm. 35.
} 
dimulai pada pertengahan tahun berjalan untuk tahun anggaran berikutnya sehingga kemungkinan ada perubahan dalam pendataan penerima dan permintaan barang. Dengan adanya perubahan tersebut secara normatif baru dapat ditampung dalam Perubahan APBD yang pada umumnya berlaku efektif bulan Oktober sampai dengan Desember, sehingga pencairannya banyak dilakukan pada bulan November dan Desember. Sebelum Program Jalinkesra tersebut diterima oleh masyarakat, Pemda Jawa Timur melakukan pendataan awal untuk dituangkan ke dalam APBD. Upaya tersebut dilakukan oleh Pemda Jawa Timur sebagai salah satu cara untuk mengetahui jumlah penerima dan mensosialisasikan kepada masyarakat menyangkut program Pemda Jawa Timur yang meliputi pembagian beras, kambing, dan becak yang didasarkan kepada permintaan masyarakat. Program tersebut merupakan salah satu kewajiban Gubernur Jawa Timur dalam menjalankan dan menggunakan APBD sebagai program daerah. Dengan demikian, penggunaan dana APBD berkaitan dengan Program Jalinkesra bukan merupakan pelanggaran Pemilukada tetapi merupakan program Pemda Jawa Timur dan tidak berkaitan dengan kampanye Pihak Terkait dalam Pemilukada Provinsi Jawa Timur Tahun 2013. Selain itu, penggunaan APBD telah diperiksa oleh Badan Pemeriksa Keuangan dan Pemda Jawa Timur telah membuat kesepakatan dengan KPK dan BPKP sebagai upaya dini pencegahan penyalahgunaan APBD Provinsi Jawa Timur. Sesuai fakta persidangan pula hal itu tidak terbukti secara signifikan mempengaruhi kebebasan para pemilih dalam menentukan pilihannya atau pun menghalang-halangi hak para calon pemilih untuk menggunakan atau tidak menggunakan hak pilihnya yang pada akhirnya mempengaruhi hasil perolehan suara khususnya antara Pemohon dan Pihak Terkait.

Terhadap dalil Pemohon yang mengatakan bahwa pihak terkait melibatkan pejabat struktural. Dalam kenyataannya tidak ada rangkaian fakta yang dapat membuktikan adanya keterlibatan PNS dan jajaran birokrasi pemerintahan di Provinsi Jawa Timur untuk pemenangan Pihak Terkait dalam Pemilukada Provinsi Jawa Timur 2013 yang terstruktur, sistematis, dan masif sehingga secara signifikan mempengaruhi perolehan suara masing-masing pasangan calon. Apabila ada dukungan secara pribadi pemilih kepada Pihak Terkait, hal itu tanpa disertai adanya tindakan yang mempengaruhi dan memprovokasi yang dilakukan oleh birokrasi dari tingkat atas sampai tingkat bawah, dengan demikian dukungan yang demikian tidak dapat dikategorikan sebagai pelanggaran yang bersifat terstruktur, sistematis, dan masif. Berdasarkan penilaian dan fakta hukum tersebut, menurut Mahkamah, dalil Pemohon a quo tidak terbukti dan tidak beralasan menurut hukum.

Menurut Mahkamah, Pemohon tidak cukup bukti yang meyakinkan bahwa Pihak Terkait terlibat dalam hal yang berhubungan dengan terpenuhi syarat atau tidak terpenuhinya syarat Pemohon menjadi peserta pasangan calon dalam Pemilukada Jawa Timur 2013. Termohon telah melakukan mekanisme pengambilan 
keputusan melalui rapat pleno Komisi Pemilihan Umum Provinsi Jawa Timur yang dihadiri oleh lima komisioner dan tidak pernah melibatkan unsur lain, seperti pejabat daerah Provinsi Jawa Timur. Termohon telah menetapkan Pemohon sebagai peserta atau Pasangan Calon Pemilukada Provinsi Jawa Timur dan mencetak surat suara dengan gambar Pasangan Calon Nomor Urut 4.

Berdasarkan fakta yang terungkap di persidangan, Termohon telah melakukan sosialisasi keempat pasangan calon Gubernur dan Wakil Gubernur dalam Pemilukada Provinsi Jawa Timur, termasuk pasangan calon Pemohon melalui berbagai media.

Menurut Mahkamah, Ketua Kelompok Penyelenggara Pemungutan Suara (KPPS) telah dilantik oleh Ketua PPS di masing-masing desa atau kelurahan dan anggota KPPS tersebut dilantik oleh Ketua KPPS. Adapun terkait dengan pemutakhiran data DPT, menurut Mahkamah sesuai fakta persidangan DPT tersebut telah dilakukan pemutakhiran sesuai saran dari Bawaslu.

Selain itu, terkait dengan permasalahan DPT yang didalilkan oleh Pemohon, bahwa sebagaimana putusan-putusan Mahkamah sebelumnya, permasalahan DPT merupakan bagian dari permasalahan kependudukan di Indonesia yang belum dapat diselesaikan oleh Pemerintah, sehingga apabila tidak dapat dibuktikan secara hukum bahwa Termohon melakukan pelanggaran DPT secara terstruktur, sistematis, dan masif yang dapat menguntungkan salah satu pasangan calon maka Termohon tidak dapat dibebani kesalahan atas kekurangan soal DPT dalam penyelenggaraan Pemilukada Provinsi Jawa Timur. Sedangkan mengenai Anggaran untuk hibah dan bantuan sosial, sesuai fakta persidangan tidak terbukti pemberian hibah dan bansos dilakukan secara terstruktur, sistematis, dan massif sehingga mempengaruhi kebebasan pemilih untuk memilih atau tidak memilih yang pada akhirnya mempengaruhi perolehan suara masing-masing pasangan calon, khususnya suara Pemohon dan Pihak Terkait.

Tentang adanya pelanggaran lainnya, menurut Mahkamah, tidak cukup bukti bahwa telah terjadi pelanggaran dalam Pemilukada Provinsi Jawa Timur Tahun 2013 yang bersifat terstruktur, sistematis, dan masif. Berdasarkan penilaian atas fakta dan hukum sebagaimana diuraikan di atas, Mahkamah berkesimpulan Pokok permohonan tidak beralasan menurut hukum dan menyatakan menolak permohonan Pemohon untuk seluruhnya.

Melalui pengacaranya, menurut mantan Ketua MK Akil Mochtar Putusan Mahkamah Konstitusi (MK) yang memenangkan pasangan Soekarwo-Saifullah Yusuf 
(Gus Ipul), dalam sengketa Pilkada Jawa Timur di MK dinilai penuh kejanggalan. Pada saat Akil Mochtar masih memimpin MK, MK telah memutuskan sengketa Pilkada Jawa Timur yang menyatakan pasangan calon Gubernur Khofifah Indar Parawangsa-Herman Suryadi Sumawiredja selaku penggugat, menangkan perkara ini. Namun setelah Akil ditangkap KPK, putusan itu menjadi berbalik dan MK menyatakan Soekarwo-Saifullah Yusuf selaku tergugat memenangkannya.

Karena sebelum Akil Mochtar ditangkap, sudah ada rapat majelis MK yang mengatakan Khofifah menang. Di samping itu, putusan MK tersebut cacat dan tidak sah karena Akil Mochtar sebagai ketua panel tidak dilibatkan dalam pengambilan keputusan. ${ }^{44}$ Menurut Akil Mochtar melalui Kuasa Hukumnya (Otto Hasibuan) menjelaskan, bahwa putusan terhadap kemenangan Khofifah-Herman itu bahkan sudah diputuskan 7 hari sebelum amar putusan dibacakan MK pada 7 Oktober 2013.45

Ketua Pergerakan Arus Perubahan Rizal Ramli menilai ada beberapa kejanggalan pada putusan Mahkamah Konstusi (MK) yang menolak gugatan hasil pilkada Provinsi Jawa Timur. Kejanggalan tersebut antara lain, majelis hakim pada persidangan tersebut berjumlah delapan orang, padahal seharusnya berjumlah ganjil. Di negara mana pun di dunia majelis hakim selalu jumlahnya ganjil, tidak ada yang genap. Kejanggalan lainnya, majelis hakim hanya mendengarkan keterangan saksisaksi dari tergugat dan banyak mengabaikan keterangan saksi-saksi penggugat. ${ }^{46}$

Anggota Tim Kuasa Hukum penggugat pasangan calon gubernur dan calon wakil gubernur Jawa Timur, Khofifah Indar Parawansa dan Herman Suryadi Sumawiredja, yakni Juli Edy menilai, Majelis Hakim Konsitusi pada persidangan putusan tidak memberikan pertimbangan yang cukup terhadap bukti-bukti dan saksi-saksi, termasuk saksi ahli dan pemohon. Majelis Hakim Konstitusi terkesan menggampangkan membuat kesimpulan bahwa dalil pemohon tidak beralasan menurut hukum, tanpa mengurai dan atau mempertimbangkan bukti-bukti dan saksi dari pemohon. ${ }^{47}$

\footnotetext{
${ }^{44}$ http://www.gatra.com. Akil nilai putusan pilgub jatim sarat kejanggalan.html. Diakses tanggal 29 Januari 2014.

${ }^{45}$ http://politik.kompasiana.com. Akil akui pemenang sengketa pemilukada jatim 2013 adalah khofifah.html. diakses tanggal 29 Januari 2014.

${ }^{46}$ http://www.antaranews.com. Rizal Ramli putusan sengketa pilkada jatim janggal. Diakses tanggal 29 Januari 2014.

${ }^{47}$ Ibid.
} 
Sementara itu, calon Gubernur Jawa Timur yang mengajukan gugatan sengketa pilkada ke Mahkamah Konstitusi, Khofifah Indar Parawansa menilai, pada amar putusan yang dibacakan oleh Majelis Hakim Konstitusi lebih berpihak kepada tergugat. Hal ini terlihat dari uraian yang dibacakan Majelis Hakim hanya menyampaikan pernyataan saksi-saksi dari pihak tergugat dan tidak menyampaikan pernyataan saksi-saksi dari pihak penggugat. ${ }^{48}$

Jika pernyataan Akil Mochtar di atas benar terdapat kecurangan, maka keputusan MK tentang sengketa Pilkada Jawa Timur Tahun 2013 harus di tinjau ulang dan MK harus memerintahkan dilakukannya Pilkada atau penghitungan suara ulang.

\section{Penutup}

Berdasarkan uraian di atas dapat disimpulkan bahwa, menurut Mahkamah Konstitusi, program Jalan Lain Menuju Kesejahteraan Rakyat (Jalin Kesra) yang dilakukan Soekarwo bukanlah kesalahan fatal dalam proses Pilkada. Menurut MK, program tersebut merupakan program berkelanjutan yang dimulai dan dilaksanakan sejak 2010. Tidak terbukti adanya keterlibatan PNS dan jajaran birokrasi pemerintahan di Provinsi Jawa Timur untuk pemenangan Pihak Terkait dalam Pemilukada Provinsi Jatim Tahun 2013 yang terstruktur, sistematis, dan masif sehingga secara signifikan mempengaruhi perolehan suara masing-masing pasangan calon.

Pertimbangan DKPP mengabulkan gugatan Khofifah-herman karena KPU terbukti menghilangkan hak konstitusional partai untuk mengusulkan calon dalam Pemilukada Jatim termasuk kepada pasangan Khofifah-Herman sebagai cagub dan cawagub.

Harus ada peraturan perundang-undangan yang mengatur bahwa program hibah dan dana sosial (bansos) harus dilaksanakan pada tiga tahun pertama pemerintahan kepala daerah sehingga jika incumbent akan mencalonkan kembali pelaksanaan kampanye dapat dilakukan secara fair, transparan dan tidak ada dugaan manipulasi dana hibah dan bansos. 


\section{Daftar Pustaka}

Agustina, Leo, Pilkada dan Dinamika Politik Lokal, Cetakan I, Pustaka Pelajar, Yogyakarta, 2009.

Arbas, Cakra, Jalan Terjal Calon Independen Pada Pemilukada Di Provinsi Aceh, Jakarta, Sofmedia, 2012.

Isnaeni Ramdhan, Muchamad, Kompedium Pemilihan Kepala Daerah (Pilkada), Badan Pembinaan Hukum Nasional Departemen hukum dan HAM RI, Jakarta, 2009.

Lutfi, Mustafa, Hukum Sengketa Pemilukada Di Indonesia Gagasan Perluasan Kewenangan Konstitusional Mahkamah Konstitusi, Cetakan Pertama, UII Press, Yogyakarta, 2010.

Mahfud MD, Moh., “Evaluasi Pemilukada Dalam Perspektif Demokrasi dan Hukum" Ceramah Kunci dalam Seminar Nasional Evaluasi Pemilukada: Antara Teori dan Praktik, diselenggarakan oleh Mahkamah Konstitusi pada RabuKamis, 25-26 Januari 2012 di Hotel Sultan Jakarta.

- Perdebatan Hukum Tata Negara Pasca Amandemen Konstitusi, Cetaka ke-2 RajaGrafindo Persada, Jakarta, 2011.

Mahmud Marzuki, Peter, Penelitian Hukum, Edisi Pertama,Cetakan Ke-4, Predana Media Group, Jakarta, 2008.

Manan, Bagir, Menyongsong Fajar Otonomi Daerah, FH UII Yogyakarta, Cet. III, 2004.

Morison, Hukum Tata Negara Era Reformasi, Jakarta: Ramdina Prakarsa, 2005.

Rizki, Faizal, http://www.aktual.co/politik. Nu menilai pilkada langsung lebih baik ditiadakan.Diakses tanggal 4 Januari 2013.

Saraswati, Retno, “Calon Perseorangan: Pergeseran Paradigma Kekuasaan Dalam Pemilukada" , dalam Masalah-Masalah Hukum, Nomor 2 Jilid 40, April 2011.

Suharizal, Pemilukada, Dinamika, dan Konsep Mendatang, Jakarta, Raja Grafindo Persada, 2011.

Wahidin, Samsul, Hukum Pemerintahan Daerah Mengawasi Pemilihan Umum Kepala Daerah, Cetakan 1, Yogyakarta: Pustaka Pelajar, 2008.

Sekretariat Jenderal MPR RI," Risalah Rapat Panitia Ad Hoc I (Sidang Tahunan 2000)", Buku kedua jilid 3C, 2000

UU No. 22 Tahun 2007 Tentang Penyelenggaraan Pemilihan Umum.

Putusan Mahkamah Konstitusi No.072-073/PUU-II-2004.

Putusan mahkamah Konstitusi Nomor 117/PHPU.D-XI/2013 tentang sengketa Pemilukada Jawa Timur.

http://ekhopratama.wordpress.com. Catatan tentang pilgub jatim 2013. Diakses tanggal 2 Oktober 2013. 
http://khofifahcenter.com.mahfud-md-dkpp-bisa-batalkan-putusan-kpu-jatim. Diakses tanggal 4 desember 2013.

http://m.koran-sindo.com. Diakses tanggal 2 Juni 2013.

http://news.detik.com.anggota kpu jatim sudah menduga khofifah menang di dkpp. Di akses tanggal 4 september 2013.

http://news.detik.com.gugatan khofifah ditolak mk kukuhkan soekarwo jadi gubernur jatim. Diakses tanggal 10 Oktober 2013.

http://news.detik.com.ini-pertimbangan-dkpp-nonaktifkan-3-komisioner-kpujatim? Diakses tanggal 20 Oktober 2013.

http://news.detik.com.langkah mundur jika pemilihan kepala daerah kembali ke tangan dprd. Diakses tanggal 10 Januari 2013.

http://news.liputan6.com. Khofifah menang. Diakses tanggal 2 September 2013.

http:// politik.kompasiana.com. Akil akui pemenang sengketa pemilukada jatim 2013 adalah khofifah.html. diakses tanggal 29 Januari 2014.

http://www.antaranews.com. Rizal Ramli putusan sengketa pilkada jatim janggal. Diakses tanggal 29 Januari 2014.

http://www.gatra.com. Akil nilai putusan pilgub jatim sarat kejanggalan.html. Diakses tanggal 29 Januarir 2014.

http://www.hukumonline.com.dkpp -70 anggota kpu bawaslu diberhentikan. Diakses tanggal 7 Juni 2013.

http://www.metro7.co.id . Solusi Pilkada Langsung.html. Di akses tanggal 3Januari 2013. http:/ / www.metrotvnews.com/metronews.Anggota KPU Gorontalo Diberhentikan karena tak Netral. Diakses tanggal 4 Juni 2013.

http://www.pewarta-kabarindonesia.blogspot.com. Di akses tanggal 2 Januari 2013.

http://www.republika.co.id.berita nasional jawa timur.soal khofifah dkpp kritik kpu jatim. Diakses tanggal 2 September 2013.

http:// www.sapujagatnews.com/yusril-dkpp-langgar-hukum-tata-negara-serie2.Diakses tanggal 4 Desember 2013.

http://www.seputar-indonesia.com. Diakses tanggal 7 Januari 2013. 